\title{
Revising order or challenging the balance of military power? An alternative typology of revisionist and status-quo states
}

\author{
Alexander Cooley ${ }^{1}$, Daniel Nexon ${ }^{2 *}$ and Steven Ward ${ }^{3}$ \\ ${ }^{1}$ Columbia University, ${ }^{2}$ Georgetown University and ${ }^{3}$ Cornell University \\ *Corresponding author. Email: dhn2@georgetown.edu
}

(Received 29 May 2018; revised 13 December 2018; accepted 21 December 2018; first published online 19 March 2019)

\begin{abstract}
Unimensional accounts of revisionism - those that align states along a single continuum from supporting the status quo to seeking a complete overhaul of the international system - miss important variation between a desire to alter the balance of military power and a desire to alter other elements of international order. We propose a two-dimensional property space that generates four ideal types: status-quo actors, who are satisfied with both order and the distribution of power; reformist actors, who are fine with the current distribution of power but seek to change elements of order; positionalist actors, who see no reason to alter the international order but do aim to shift the distribution of power; and revolutionary actors, who want to overturn both international order and the distribution of capabilities. This framework helps make sense of a number of important debates about hegemony and international order, such as the possibility of revisionist hegemonic powers, controversies over the concept of 'soft balancing', and broader dynamics of international goods substitution during power transitions.
\end{abstract}

Keywords: Revisionism; Balancing; International Order; Hegemony

\section{Introduction}

The George W. Bush administration's strategy of 'preemption', its 2003 invasion of Iraq, and its embrace of 'enhanced interrogation techniques' led a number of observers to label the United States a 'revisionist state' or to describe the Bush administration as seeking to revise the international order. ${ }^{1}$ Writing of the emerging 'Bush doctrine', G. John Ikenberry argued that 'America's older strategic orientations - balance-of-power realism and liberal multilateralism suggest a mature world power that seeks stability and pursues its interests in ways that do not fundamentally threaten the positions of other states.' In contrast, the Bush administration's 'new imperial grand strategy presents the United States very differently': as 'a revisionist state seeking to parlay its momentary power advantages into a world order in which it runs the show'.

\footnotetext{
${ }^{1}$ See Ian Hurd, 'Breaking and making norms: American revisionism and crises of legitimacy', International Politics, 44:2 (2007), pp. 194-213; Yasuhiro Izumikawa, 'Strategic innovation or strategic nonsense? Assessing the Bush administration's national security strategy', Japanese Journal of American Studies, 15 (2004), pp. 257-72; Ryder McKeown, 'Norm regress: US revisionism and the slow death of the torture norm', International Relations, 23:1 (2009), pp. 5-25; Carlos L. Yordán, 'America's quest for global hegemony: Offensive realism, the Bush doctrine, and the 2003 Iraq War', Theoria, 53:110 (2006), pp. 125-57.

${ }^{2}$ G. John Ikenberry, 'America's imperial ambition', Foreign Affairs, 81:5 (2002), p. 60.

(c) British International Studies Association 2019
} 
In the face of Donald Trump's 'America First' foreign policy, observers once again worry about the United States turning revisionist. ${ }^{3}$ On the campaign trail, Trump repeatedly claimed that the existing international order weakens the United States. Previous American presidents and diplomats, according to Trump, struck terrible international bargains on trade, arms control, and alliances. Looking back on over a year of Trump foreign policy, Kori Schake argues that, 'quite explicitly, the leader of the free world wants to destroy the alliances, trading relationships and international institutions that have characterized the American-led order for 70 years' ${ }^{4}$

The notion of revisionist hegemons - along with the possibility that rising powers or secondtier great powers might seek to conserve international order against an established hegemon - is not incompatible, per se, with prevailing understandings of revisionism. But it is analytically thorny, inasmuch as prominent understandings associate hegemons with status-quo orientations and rising challengers with revisionist ones; ${ }^{5}$ collapse together opposition to the prevailing distribution of power with opposition to international order, that is, 'the settled rules and arrangements between states that define and guide their interactions'; ${ }^{6}$ and tend to arrange revisionism along a linear continuum form minimal to maximalist. ${ }^{7}$

We advance, by contrast, a disaggregated understanding of revisionism that distinguishes between two distinct dimensions along which states can seek change: the international order and the distribution of military capabilities. ${ }^{8}$ These dimensions produce four ideal typical orientations: status-quo actors are satisfied with both the greater order and the distribution of power; reformist powers express satisfaction with the current distribution of power but seek to change other elements of order; positionalist actors express satisfaction with international order but aim to shift the distribution of power; and revolutionary ones aim to revise both international order and the distribution of capabilities. ${ }^{9}$

\footnotetext{
${ }^{3}$ G. John Ikenberry, 'The plot against American foreign policy', Foreign Affairs, 96:3 (2017), pp. 2-9; Doug Stokes, 'Trump, American hegemony and the future of the liberal international order', International Affairs, 94:1 (2018), p. 133.

${ }^{4}$ Kori Schake, 'The Trump Doctrine Is Winning and the World Is Losing', available at: \{https://www.nytimes.com/2018/06/ 15/opinion/sunday/trump-china-america-first.html\} accessed 12 December 2018; see also Rebecca Friedman Lissner and Mira Rapp-Hooper, 'The day after Trump: American strategy for a new international order', The Washington Quarterly, 41:1 (2018), p. 18.

${ }^{5}$ Alastair Iain Johnston, 'Is China a status quo power?', International Security, 27:4 (2003), pp. 5-56; Baohui Zhang, China's Assertive Nuclear Posture: State Security in an Anarchic International Order (London: Routledge, 2015), p. 153.

${ }^{6}$ G. John Ikenberry, Liberal Leviathan: The Origins, Crisis, and Transformation of the American World Order (Princeton, NJ: Princeton University Press, 2011), p. 12.

${ }^{7}$ For critical overviews of conventional treatments of revisionism, see Steven Ward, 'Race, status, and Japanese revisionism in the early 1930s', Security Studies, 22:4 (2013), pp. 608-09; see also Steven Ward, 'Status Immobility and Systemic Revisionism in Rising Great Powers' (PhD dissertation, Georgetown University, Washington, DC, 2012); Steven Ward, Status and the Challenge of Rising Powers (New York, NY: Cambridge University Press, 2017).

${ }^{8}$ Johnston, 'Is China a status quo power?', pp. 10-11; compare Ward, Status and the Challenge of Rising Powers, pp. 1-2, 11-21. Following conventional usage, we use terms such as 'balance of power' and 'distribution of capabilities' interchangeably to refer to the distribution of military capabilities in the international system. Of course, power is much more than military capabilities; even scholars who use the term 'balance of power' often refer to some combination of military capabilities and economic resources that could be converted into military power. But we follow the literature, and thus specify when we mean something different. On the problems with this conventional usage, see, for example, David A. Baldwin, Paradoxes of Power (Cambridge: Basil Blackwell, 1989); Stacie E. Goddard and Daniel H. Nexon, 'The dynamics of global power politics: a framework for analysis', Journal of Global Security Studies, 1:1 (2016), pp. 4-18; Stefano Guzzini, 'Structural power: the limits of neorealist power analysis', International Organization, 47:3 (1993), pp. 443-78.

${ }^{9}$ While we will generally refer to 'states', we use 'actors' here to highlight that this typology should provide purchase not only on states and other polities, but also on non-state actors of various kinds. On non-state actors and security studies, see Fiona B. Adamson, 'Globalization, transnational political mobilization, and networks of violence', Cambridge Review of International Affairs, 18:1 (2005), pp. 21-49; Fiona B. Adamson, 'Spaces of global security: Beyond methodological nationalism', Journal of Global Security Studies, 1:1 (2016), pp. 19-35; Elke Krahmann, 'From state to non-state actors: the emergence of security governance', in Elke Krhamann (ed.), New Threats and New Actors in International Security (New York, NY: Springer, 2005), pp. 3-19.
} 
This typology helps make sense of 'revisionist' hegemonic powers. It also helps synthesise a number of threads in current discussions of unipolarity, balancing, hegemony, power transitions, and international order. ${ }^{10}$ In particular, it accords with a greater focus on the power politics of international order - as something analytically distinct from the prevailing balance (or distribution) of military capabilities. ${ }^{11}$ We develop this argument through a discussion of the debate over 'soft balancing' and the elaboration of a class of power-political activity involving international goods substitution. Finally, we conclude by spinning out some additional implications. We emphasise that, while we believe our typology has heuristic value, it points towards even more granular understandings of international order than those that we offer.

\section{Revisionism}

The concept of revisionism - and its opposite, an orientation towards the status quo - plays an important role in contemporary International Relations (IR) theory in general, and in hegemonic-order theories in particular. $^{12}$ In power transition and hegemonic stability approaches, the degree to which rising powers adopt status-quo or revisionist orientations helps explain whether or not international systems experience generalised, great power wars.

In brief, these theories see world politics as driven by the rise and decline of 'hegemonic' or 'leading' powers. Dominant polities use their superior economic and military capabilities to order international systems. That is, they 'establish the rules of the game; provide impure public, club, and private goods - such as security and trading systems; allocate status and prestige; and even shape "domestic politics" in subordinate polities'. ${ }^{13}$ International order itself is structured by the form, content, and extent of the goods provided by the hegemon. But many of the 'carrots and sticks' that hegemons use to maintain international order involve the provision or withdrawal of such goods, including access to markets and security assistance.

Over time, various forces - uneven growth, the costs of maintaining the order, and so on conspire to redistribute relative power away from the hegemon. If emerging powers are status-quo powers - satisfied with the order - then the order endures. If they are revisionist - want, for example, greater status or a change in the rules of the game - then the hegemon either has to accommodate them or will face increasing challenges to its authority and position. The latter dynamic often, the arguments goes, culminates in a system-wide war. If the hegemon prevails, it enjoys a new window of opportunity to conserve or restructure international order. If the challenger prevails, then it will create an order that serves its own interests and values. ${ }^{14}$

\footnotetext{
${ }^{10}$ See, for example, Deborah Welch Larson, 'New perspectives on rising powers and global governance: Status and clubs', International Studies Review, 20:2 (2018), pp. 247-54; Douglas Lemke and Suzanne Werner, 'Power parity, commitment to change, and war', International Studies Quarterly, 40:2 (1996), pp. 235-60; T. V. Paul (ed.), Accommodating Rising Powers: Past, Present, and Future (Cambridge: Cambridge University Press, 2016); Stephen M. Walt, 'Alliances in a unipolar world', World Politics, 61:1 (2009), pp. 86-120.

${ }^{11}$ See G. John Ikenberry and Daniel H. Nexon, 'Hegemony studies 3.0: Hegemonic-order theory', Security Studies (forthcoming, 2019); Janice Bially Mattern and Ayşe Zarakol, 'Hierarchies in world politics', International Organization, 70:3 (2016), pp. 623-54; Ward, Status and the Challenge of Rising Powers.

${ }^{12}$ For a comprehensive survey of prominent treatments of revisionism, see Ward, Status and the Challenge of Rising Powers, ch. 1. We use 'hegemonic order theory' as a covering term for power transition, hegemonic stability, and other theories that share the characteristics elaborated here and in Ikenberry and Nexon ('Hegemony studies 3.0'); See also Paul Y. Hammond, LBJ and the Presidential Management of Foreign Relations (Austin, TX: University of Texas Press, 1992), p. 222; Daniel H. Nexon and Thomas Wright, 'What's at stake in the American empire debate', American Political Science Review, 101:2 (2007), p. 8.

${ }^{13}$ Daniel H. Nexon and Iver B. Neumann, 'Hegemonic-order theory: a field-theoretic account', European Journal of International Relations, 24:3 (2018), p. 3.

${ }^{14}$ Margit Bussmann and John R. Oneal, 'Do hegemons distribute private goods?: A test of power-transition theory', Journal of Conflict Resolution, 51:1 (2007), pp. 88-111; Jonathan M. DiCicco and Jack S. Levy, 'Power shift and problem shifts: the evolution of the power transition research program', Journal of Conflict Resolution, 43:6 (1999), pp. 675-704; Robert Gilpin, War and Change in World Politics (New York: Cambridge University Press, 1981); Joanne Gowa, 'Rational hegemons,
} 
Neoclassical realists also often stress the importance of the revisionist or status-quo dispositions of states. ${ }^{15}$ Some neoclassical realist theories aim to explain why states adopt, and pursue, more revisionist or more status-quo agendas. Others treat it as an important explanatory variable. ${ }^{16}$ Moreover, neoclassical realists maintain that revisionism explains otherwise puzzling alliance behaviour, such as when states bandwagon with aggressive, threatening powers. All things being equal, states of a feather flock together; Randall L. Schweller argues that: 'Satisfied powers will join the status-quo coalition, even when it is the stronger side; dissatisfied powers, motivated by profit more than security, will bandwagon with an ascending revisionist state. ${ }^{, 17}$

\section{Conceptualising revisionism}

Contemporary scholarship tends to understand revisionism as referring to some sort of dissatisfaction with the state of affairs in the world. The most common approaches to revisionism place it on one side of a one-dimensional continuum defined by the costs a state will bear to alter, or defend, the status quo. Thus, a 'total revisionist' seeks change at any cost; an entirely status-quo state will pay any price to conserve the existing international system. In the middle lies an indifferent state: one unwilling to expend resources to either challenge or defend the status quo. As we move right or left on the continuum, we find incremental changes in the intensity of dissatisfaction or satisfaction that, in standard accounts, drive changes in the relative costs states are willing to incur for either purpose. Schweller's influential work exemplifies this approach: it maps 'statusquo' and 'revisionist' orientations in terms of variation along a single value - the willingness to pay to change versus uphold the status quo. ${ }^{18}$

This confuses more than it clarifies. For one thing, it tells us nothing about what a revisionist state is dissatisfied with. Scholars sometimes develop lists of things revisionist states find unsatisfactory. These include prevailing norms, rules, institutions, allocations of territory and prestige, and distributions of capabilities. ${ }^{19}$ But very few spend much time theorising the relationship among such sources of dissatisfaction, or how they might affect revisionist strategies and

excludable goods, and small groups: an epitaph for hegemonic stability theory?', World Politics, 41:3 (1989), pp. 307-24; Isabelle Grunberg, 'Exploring the "myth" of hegemonic stability', International Organization, 44:4 (1990), pp. 431-77; Ikenberry, Liberal Leviathan; David A. Lake, 'Leadership, hegemony, and the international economy: Naked emperor or tattered monarch?', International Studies Quarterly, 37:4 (1993), pp. 459-89; Lemke and Werner, 'Power parity'; A. F. K. Organski and Jacek Kugler, The War Ledger (Chicago: University of Chicago Press, 1980); Duncan Snidal, 'The limits of hegemonic stability theory', International Organization, 39:4 (1985), pp. 579-614; Michael C. Webb and Stephen D. Krasner, 'Hegemonic stability theory: an empirical assessment', Review of International Studies, 15:2 (1989), pp. 183-98.

${ }^{15}$ For an overview of neoclassical realist approaches, see Norrin M. Ripsman, Jeffrey W. Taliaferro, and Steven E. Lobell (eds), Neoclassical Realist Theory of International Politics (Oxford: Oxford University Press, 2016).

${ }^{16}$ Jason W. Davidson, 'The roots of revisionism: Fascist Italy, 1922-39', Security Studies, 11:4 (2002), pp. 125-59; Jason W. Davidson, The Origins of Revisionist and Status-Quo States (New York: Palgrave MacMillan, 2006); Neal Jesse, Steven Lobell, Galia Press-Barnathan, and Kristen Williams, 'The leader can't lead when the followers won't follow: the limitations of hegemony', in Kristen Williams, Steven Lobell, and Neal Jesse (eds), Beyond Great Powers and Hegemons: Why Secondary States Support, Follow, or Challenge (Stanford, CA: Stanford University Press, 2012), pp. 1-32; Gideon Rose, 'Neoclassical realism and theories of foreign policy', World Politics, 51:1 (1998), pp. 144-72; Sten Rynning and Jens Ringsmose, 'Why are revisionist states revisionist? Reviving classical realism as an approach to understanding international change', International Politics, 45:1 (2008), pp. 19-39; Randall L. Schweller, Unanswered Threats: Political Constraints on the Balance of Power (Princeton, NJ: Princeton University Press, 2006).

${ }^{17}$ Randall L. Schweller, 'Bandwagoning for profit: Bringing the revisionist state back in', International Security, 19:1 (1994), p. 88 .

${ }^{18}$ Schweller, 'Bandwagoning for profit', p. 100.

${ }^{19}$ Davidson, The Origins of Revisionist and Status-Quo States; Nuno P. Monteiro, 'Unrest assured: Why unipolarity is not peaceful', International Security, 36:3 (2011), p. 14. This arguably misreads some early writings on revisionism, which focus on strategies and see affecting the balance of power as a means of altering or conserving the distribution of goods. However, hegemonic-order theories, especially when conjoined to debates about unipolarity, tend to reflect this more expansive list. 
dispositions. Does a state dissatisfied with its territorial holdings behave in similar ways to a state frustrated with prevailing (or specific) international institutions? Should defenders of the status quo handle them differently, regardless of whether the two are equally intense in their desire to change?

Even worse, these unidimensional approaches make it difficult to consistently distinguish between revisionist and status-quo orientations. Consider, for instance, a state that aspires to improve its share of military power. The desire to become more powerful clearly constitutes dissatisfaction with a key element of the current international system. But what if the state seeks a more favourable balance of capabilities to defend the territorial or institutional order?

In part because of this failure to distinguish between different dimensions of the status quo, common approaches face difficulty making sense of how or why a hegemon might 'turn revisionist'. For instance, the George W. Bush administration clearly saw itself as revising some elements of order. It also aimed to conserve 'American hegemony'. ${ }^{20}$ The combination of these two impulses do not simply sum, which complicates any attempt to locate the United States under Bush on a continuum ranging from more to less dissatisfied. In fact, the assumption that dominant powers in general, and hegemonic ones in particular, are necessarily status-quo oriented runs deep. We have already seen that many hegemonic-order theories assume that the dominant power upholds the status quo; they associate revisionist dispositions with rising powers. ${ }^{21}$ As Alistair Johnston notes, for example, 'power-transition theorists' view 'status quo states as those that have participated in designing the "rules of the game" and stand to benefit from those rules'. In contrast, 'revisionist states express a "general dissatisfaction" with their "position in the system". They have a "desire to redraft the rules by which relations among nations work". 22

In response to these problems, a handful of IR theorists have sought to construct multidimensional approaches to revisionism. They aim to conceptualise the implications not just of the intensity of revisionism or satisfaction with current international arrangements, but also of the different elements of order at stake. They contend that revisionism varies not simply quantitatively but also qualitatively, and argue that making this variation explicit helps clarify variation in the behaviour and strategies of revisionist powers. ${ }^{23}$

Thus, Steven Ward proposes a two-dimensional conception of revisionism. He distinguishes between distributive dissatisfaction - the desire to acquire more of some resource, such as military power or economic influence - and normative dissatisfaction - unhappiness with the rules, norms, and institutions that legitimise the existing distribution of resources. This allows for, among other things, a better specification of what causes rising powers to mount different kinds of revisionist challenges, and particularly why some states - such as Japan before the Second World War - shift from what are often limited attempts to improve their positions in the world towards more radical challenges to the broader order. ${ }^{24}$

We follow Ward in distinguishing between different objects of dissatisfaction. However, we adopt a different, albeit closely related, way of disaggregating revisionism: in terms of, on the one hand, the balance of power and, on the other hand, other elements of international order understood in terms of the distributions of other goods in world politics. Why take this approach? As we note below, even two-dimensional frameworks oversimplify variation in orientations towards the status quo. But as heuristic devices, frameworks that adopt different

\footnotetext{
${ }^{20}$ Brian C. Schmidt and Michael C. Williams, 'The Bush doctrine and the Iraq War: Neoconservatives versus realists', Security Studies, 17:2 (2008), p. 198.

${ }^{21}$ Zhang, China's Assertive Nuclear Posture, p. 153.

${ }^{22}$ Johnston, 'Is China a status quo power?', p. 9.

${ }^{23}$ Stacie E. Goddard, 'Embedded revisionism: Networks, institutions, and challenges to world order', International Organization, 72:4 (2018), pp. 763-97; Ward, 'Status Immobility'; Ward, 'Race, status, and Japanese revisionism'; Ward, Status and the Challenge of Rising Powers.

${ }^{24}$ Ward, 'Race, status, and Japanese revisionism'.
} 
approaches to 'carv[ing] nature at its joints' can provide distinctive insights into specific debates. $^{25}$

We focus on the balance of power because of its importance in hegemonic-order theories and related debates over unipolar stability. For example, Robert Gilpin identifies three elements of the 'governance of an international system': the 'distribution of power', the 'hierarchy of prestige', and a 'set of rights and rules'. He argues that the distribution of power matters most, as it is the 'great powers' that 'establish and enforce' rights and rules and because 'the hierarchy of prestige' depends upon 'economic and military power. ${ }^{26}$ In general, hegemonic-order theorists agree that an actor - almost always a militarily and economically dominant power in a unipolar system - exercises hegemony, 'the mobilization of leadership', ${ }^{27}$ to create, or profoundly shape, the distribution of other goods, such as territory, alliances, institutional voice, international regimes, status, and prestige.

Thus, Johnston differentiates between 'the question of how proactive an actor is in challenging formal and informal rules of the major institutions in the international system that most other actors support most of the time' and 'the attitudes and behavior of an actor toward distributions of material power that appear to be disadvantageous to it'. ${ }^{28}$ Along similar lines, Nuno P. Monteiro argues that understanding the dynamics of unipolar systems depends on how the dominant actor views the status quo, which he defines in terms of prevailing 'territorial arrangements, international political alignments, and the global distribution of power'. ${ }^{29}$

More broadly, we know that different hegemons establish orders that differ significantly in terms of not only the way that they distribute goods, but also the kinds of goods at stake. These aspects of international order also vary over the course of a hegemonic lifecycle. ${ }^{30}$ American-led international order, for example, looks different than international order during the period associated with British hegemony. ${ }^{31}$ Moreover, all hegemonic orders are international orders, but not all international orders are hegemonic. 'Great-power cartels', such as during the European Concert system, may uphold and shape international order even in the absence of a clear hegemon; international orders may rest on 'generalized consent', or manifest as 'emergent properties of the interaction among polities' ${ }^{32}$

Ward's typology, as noted above, deals with this complexity by differentiating between the distribution of goods, including the balance of military capabilities and constitutive norms and rules. This serves primarily to make sense of variation in the orientations of rising powers. It also helps explain why such states - who should display caution in how they challenge dominant powers -

\footnotetext{
${ }^{25}$ Michael Barnett and Raymond Duvall, 'Power in international politics', International Organization, $59: 1$ (2005), p. 43.

${ }^{26}$ Gilpin, War and Change in World Politics, pp. 28-34.

${ }^{27}$ Alexander D. Barder, 'International hierarchy', Oxford Research Encyclopedia of International Studies (2015).

${ }^{28}$ Johnston, 'Is China a status quo power?', pp. 10-11.

${ }^{29}$ Monteiro, 'Unrest assured', p. 14.

${ }^{30}$ Ian Clark, 'Bringing hegemony back in: the United States and international order', International Affairs, 85:1 (2009), pp. 23-36; Goddard, 'Embedded revisionism'; Charles A. Kupchan, 'The normative foundations of hegemony and the coming challenge to Pax Americana', Security Studies, 23:2 (2014), pp. 219-57; Carla Norrlof, America's Global Advantage: US Hegemony and International Cooperation (Cambridge: Cambridge University Press, 2010); John Gerard Ruggie, 'International regimes, transactions, and change: Embedded liberalism in the postwar economic order', International Organization, 36:2 (1982), pp. 379-415; Ward, Status and the Challenge of Rising Powers.

${ }^{31}$ Clark, 'Bringing hegemony back in', pp. 27-34; Julian Go, Patterns of Empire: The British and American Empires, 1688 to the Present (Cambridge: Cambridge University Press, 2012).

${ }^{32}$ Paul Musgrave and Daniel Nexon, 'Defending hierarchy from the moon to the Indian Ocean: Symbolic capital and political dominance in early modern China and the Cold War', International Organization, 72:3 (2018), p. 6; See also Mlada Bukovansky, Legitimacy and Power Politics: The American and French Revolutions in International Political Culture (Princeton: Princeton University Press, 2002); Marjo Koivisto and Tim Dunne, 'Crisis, what crisis? Liberal order building and world order conventions', Millennium: Journal of International Studies, 38:3 (2009), pp. 615-40; Jennifer Mitzen, 'Reading Habermas in anarchy: Multilateral diplomacy and global public spheres', American Political Science Review, 99:3 (2005), pp. 401-17; Clark ('Bringing hegemony back in'), describes many of these examples as different varieties of hegemony.
} 
fail to send reassuring signals that they accept prevailing rules, norms, and arrangements while they are seeking to revise the distribution of resources.

In contrast, we focus on the possibility of revisionist hegemons and on a series of debates that arise out of the relationship between theories of hegemony and of unipolarity. ${ }^{33}$ Thus, we separate state orientations towards the balance of power from other aspects of international order. Of course, the balance of power - understood in terms of the distribution of military capabilities remains an element of the distribution of goods. ${ }^{34}$ But as we explore later, hiving power off from other kinds of goods facilitates a useful conceptual symmetry: just as actors might object to the allocation of goods that we shorthand as 'international order' here, they also might reject the allocation of military capabilities. Both can also be further disaggregated. Military capabilities, for example, include a range of more specific military and security goods. ${ }^{35}$

Viewing international order in terms of a distribution of different kinds of goods highlights different analytical possibilities than previous efforts to disaggregate revisionism. It is relatively easy to recode, for instance, in language associated with practice theory, such as social fields and field-relevant capital. It thus might be adapted along more social-constructionist lines, especially if we later integrate the important difference between the positional dimensions of fields and their relational aspects - that is, their rules of the game. ${ }^{36}$

\section{Beyond status-quo and revisionist states}

Figure 1 shows an ideal-typical property space based on two dimensions of revisionism: opposition to international order and opposition to the current distribution of power. Any given actor might vary in terms of its preferences with respect to the international order and the current balance of power (distribution of capabilities), ranging from completely satisfied to completely dissatisfied. ${ }^{37}$ Ideal-typical status-quo actors express satisfaction with both the current distribution of capabilities and the nature of the international order. Reformist orientations combine a desire to change the terms of the order and satisfaction with the existing distribution of capabilities. Positionalist ones accept the terms of the current order, but would like to see a change in the distribution of capabilities. In other words, reformists are order revisionists, while positionalists are distribution-of-power revisionists. Ideal-typical revolutionary actors are dual-revisionists: they want to overturn both the distribution of capabilities and the broader order. ${ }^{38}$

\footnotetext{
${ }^{33}$ This entails a focus on realist and rationalist approaches, which, as we have seen, treat place capabilities at the centre of their analysis.

${ }^{34}$ Which is why Goddard, 'Embedded revisionism'; and Ward, Status and the Challenge of Rising Powers put all these elements in a single basket.

${ }^{35}$ Compare Elke Krahmann, 'Security: Collective good or commodity?', European Journal of International Relations, 14:3 (2008), pp. 379-404; Todd Sandler and Keith Hartley, 'Economics of alliances: the lessons for collective action', Journal of Economic Literature, 39:3 (2001), pp. 869-96.

${ }^{36}$ Rebecca Adler-Nissen, 'Stigma management in international relations: Transgressive identities, norms, and order in international society', International Organization, 68:1 (2014), pp. 143-76; Rebecca Adler-Nissen and Vincent Pouliot, 'Power in practice: Negotiating the international intervention in Libya', European Journal of International Relations, 20:4 (2014), pp. 889-911; Trine Villumsen Berling, 'Bourdieu, international relations, and international security', Theory and Society, 41 (2012), pp. 451-78; Didier Bigo, 'Pierre Bourdieu and International Relations: Power of practices, practices of power', International Political Sociology, 5:3 (2012), pp. 225-58; David M. McCourt, 'Practice theory and relationalism as the new constructivism', International Studies Quarterly, 60:3 (2016), pp. 475-85; Musgrave and Nexon, 'Defending hierarchy from the moon to the Indian Ocean'; Nexon and Neumann, 'Hegemonic-order theory'; Florent Pouponneau and Frédéric Mérand, 'Diplomatic practices, domestic fields, and the international system: Explaining France's shift on nuclear nonproliferation', International Studies Quarterly, 61:1 (2017), pp. 123-35.

${ }^{37}$ At the risk of repetition, we aggregate these for the purposes of developing a simple typology. Actors can be 'reformist' or 'positionalist' with respect to more specific goods or, alternatively, capital.

${ }^{38}$ Our language here is similar to Barry Buzan, 'China in international society: Is "peaceful rise” possible?', The Chinese Journal of International Politics, 3:1 (2010), pp. 17-18. He uses terms like 'revolutionary' and 'reformist' to signal increasing levels of dissatisfaction with international society.
} 


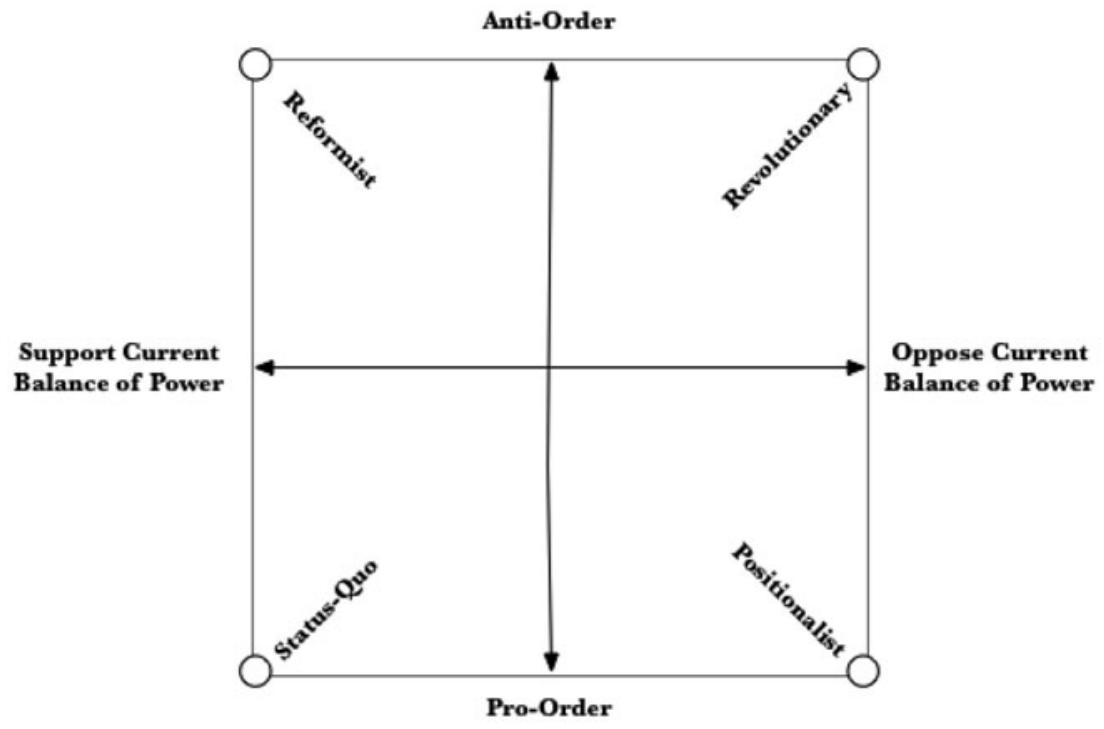

Figure 1. Varieties of revisionist and status-quo orientations.

Note that, although the text of four types - reformist, revolutionary, status-quo, and positionalist - is located inside the property space, they actually label the corners (the circles at the intersections): 'Researchers construct ideal types in order to create an idealization of a phenomenon's characteristics that can then be compared against other, related empirical instances.' Thus, 'ideal types will never accurately or exhaustively describe the concrete manifestations of a specific phenomenon, but they do provide benchmarks for the analytical comparison of real phenomena. ${ }^{39}$

In this section, we elaborate each of these ideal types and discuss some general propositions, including about potential pathways of movement across the property space associated with them.

\section{Revolutionary states}

We borrow this label from Kissinger's notion of a 'revolutionary power'. As he notes, 'Whenever there exists a power which considers the international order or the manner of legitimizing it oppressive, relations between it and other powers will be revolutionary. In such cases, it is not the adjustment of differences within a given which will be at issue, but the system itself. ${ }^{40}$ Revolutionary states are akin to Ward's category of 'radical' revisionism, ${ }^{41}$ which describes 'a grand strategic orientation that rejects and challenges the international status quo at its most basic levels' - that is, 'the hegemonic leadership of the system and/or the constitutive norms, principles, and rules that undergird the system's hierarchic and normative structure. ${ }^{42}$

In this framework, the ideal-typical revolutionary state (or actor) is similar to a radical revisionist, but defined as a state that simultaneously challenges the balance of military capabilities

\footnotetext{
${ }^{39}$ Patrick Thaddeus Jackson and Daniel H. Nexon, 'Paradigmatic faults in International-Relations theory', International Studies Quarterly, 53:4 (2009), p. 921; See also Patrick Thaddeus Jackson, The Conduct of Inquiry in International Relations: Philosophy of Science and its Implications for the Study of World Politics (London: Routledge, 2011), pp. 142-55.

${ }^{40}$ Henry Kissinger, A World Restored: Metternich, Castlereagh, and the Problems of Peace, 1812-22 (Pickle Partners Publishing, 2017), p. 2.

${ }^{41}$ Ward, Status and the Challenge of Rising Powers, ch. 1.

${ }^{42}$ Ward, 'Race, status, and Japanese revisionism', pp. 608-09.
} 
and the distributions of other goods that make up order. ${ }^{43}$ Real-world actors may combine relatively high levels of both orientations without reaching something close to the ideal-typical limit. ${ }^{44}$ In other words, we should expect to see substantial variation in the intensity and mix of revolutionary orientations. This suggests pathways relevant to the development of revolutionary dispositions.

Ward's account of shifts towards radical revisionism identifies one such pathway: rising states sometimes start out seeking greater status but, as dominant powers repeatedly rebuff their efforts, conclude that this is not possible without much broader changes in international order. ${ }^{45}$ That process might then lead to an attempt to further shift the balance of capabilities in order to more effectively challenge the order - a shift from a reformist to a revolutionary orientation. Indeed, this line of reasoning tracks with Arnold Wolfers's understanding of revisionist states: as seeking to alter the balance of power in order to enact a desired change in the international order. $^{46}$

Alternatively, actors may begin by trying to alter the balance of power (rather than, say, the hierarchy of status) but come to believe that the broader order acts as a barrier to their efforts. This may prompt a move from positional to revolutionary orientations. For example, a regional power may view its security as threatened by a gap between its own military capabilities and those of a neighbour but find the tools of international order deployed against its efforts to acquire weapons or otherwise enhance its military prowess. In general, if the dominant order itself is stacked against a more favourable distribution of power, then a state may conclude that achieving greater military capabilities requires challenging the broader order.

Many existing approaches assume, for good reason, that the dynamics that move states towards the 'revolutionary' limit often involve an iterative and mutually reinforcing interaction between these two pathways. Nonetheless, even when this is likely the case, we that think distinguishing between the two forms of revisionism helps to make sense of important controversies. For instance, observers dispute the sources of contemporary Russian revisionism. Some argue that Russia is security-seeking, and that it views the Western-dominated order as an impediment to its security because of some combination of the environment created by NATO enlargement and the ways in which liberal order threatens domestic stability. This reflects a positionalist-to-revolutionary pathway. Others argue that it primarily wants improved international status, and that efforts to alter the balance of power stem from its conclusion that it cannot achieve that in the face of American hegemony. This reflects a reformist-to-revolutionary pathway. 47

Regardless, for revolutionary actors, the distinction between the distribution of capabilities and other elements of order tends to collapse. It is not just that they reject both, but that as they become more revisionist they increasingly see the two as inseparable. In this sense, the category is well-trod in prevailing approaches - that is, those that aggregate both objects of dissatisfaction into a single category of 'revisionism'; in hegemonic systems, power-political activities of revolutionary revisionists will tend to be comprehensively counter-hegemonic in character, rather than predominately counter-order or counter-capabilities.

\footnotetext{
${ }^{43}$ Ward uses the term 'maximal' revisionism as a synonym for radical revisionism. See Ward, 'Race, status, and Japanese revisionism'.

${ }^{44}$ For an example of a revolutionary non-state actor, al-Qaeda in the 2000s, see Daniel Philpott, 'Usurping the sovereignty of sovereignty?', World Politics, 53 (2001), pp. 297-324.

${ }^{45}$ Ward, 'Race, status, and Japanese revisionism'; Ward, Status and the Challenge of Rising Powers, ch. 2.

${ }^{46}$ Arnold Wolfers, Discord and Collaboration: Essays on International Politics (Baltimore, MD: The Johns Hopkins University Press, 1965), pp. 18-19, 96, and 126.

${ }^{47}$ See, for example, Deborah Welch Larson and Alexei Shevchenko, 'Status seekers: Chinese and Russian responses to U.S. primacy', International Security, 34:4 (2010), pp. 63-95; Iver Neumann and Vincent Pouliot, 'Untimely Russia: Hysteresis in Russian-Western relations over the past millennium', Security Studies, 20:1 (2011), pp. 105-37.
} 
Calling 'revolutionary' what many scholars aggregate as 'revisionist' states also helps us to understand a potential paradox in hegemonic-order theories. Some argue that Moscow is much more aggressively 'revisionist' than Beijing at the present moment. But Russia faces a downward trajectory and China's power-political future looks much brighter. If aspirations track capabilities, we should expect Beijing to mount a more aggressive challenge to international order. Some explanations for this point to differences in domestic politics. But others point to the fact that China is simply doing better under the current international order. Russia faces a closing window of opportunity, China an opening one. ${ }^{48}$

We think all of these considerations matter, but Russia and China also reflect a possible empirical pattern in which rising challengers have less reason to behave in revolutionary ways, in relative terms, than weaker or declining states. This pattern makes sense if we disaggregate revisionism. Those states that see the balance of power as shifting in their favour face, all things being equal, less pressure towards the 'positionalist' dimension of revisionism. They also have incentives to bide their time before pursuing serious challenges to the other elements of order. ${ }^{49}$ This not only inflects their understanding of the costs and benefits of the current international order. It also, in principle, may make it easier for them to distinguish between that prevailing balance of capabilities and the prevailing international order. This, in turn, creates more opportunities for adjustment and bargaining. But states whose positions seem to be eroding may face greater incentives to take risks in order to avert decline along the positional dimension - or to satisfy outstanding ambitions related to the other elements of order before it is too late.

\section{Positionalist states}

Ideal-typical positionalists are satisfied with prevailing rules, norms, institutions, and with the distribution of international goods other than military capabilities, but reject the existing balance of power. This differs from Joseph Grieco's description of states as 'defensive positionalists' by assumption: the idea that states always worry about maintaining their relative position and therefore will avoid pareto-improving cooperation when it leaves them relatively worse off than their partners. ${ }^{50}$ Indeed, realists tend to divide on whether states generally embrace 'offensive positionalism' - seek to maximise their relative power - or 'defensive positionalism' - seek to maintain their relative power. ${ }^{51}$

In unidimensional accounts, states that seek to alter the distribution of power out of, for example, parochial security concerns - to correct a perceived security deficit - are usually coded as status-quo states or mildly revisionist ones. But this masks variation between revolutionary actors, who seek to alter the distribution of power as part of an effort to change other elements of order, and positionalist actors, who may aim to alter the distribution of power to maintain the broader order.

This suggests a pathway, from a more status-quo to more positionalist orientation, in which states seek to alter the distribution of capabilities in order to meet the challenge of reformist

\footnotetext{
${ }^{48}$ See Evan A. Feigenbaum, 'Reluctant Stakeholder: Why China's Highly Strategic Brand of Revisionism is More Challenging Than Washington Thinks', available at: $\{$ https://macropolo.org/reluctant-stakeholder-chinas-highly-strategicbrand-revisionism-challenging-washington-thinks/\} accessed 23 May 2018. For an influential application of power-transition theory to Sino-US relations, see Graham Allison, Destined for War: Can America and China Escape Thucydides's Trap? (Dublin: Houghton Mifflin Harcourt, 2017).

${ }^{49}$ Ward, Status and the Challenge of Rising Powers, ch. 1.

${ }^{50}$ Joseph Grieco, 'Anarchy and the limits of cooperation: a realist critique of the newest liberal institutionalism', in David A. Baldwin (ed.), Neorealism and Neoliberalism: The Contemporary Debate (New York: Columbia University Press, 1993), pp. 116-42.

${ }^{51}$ Sorpong Peou, 'Realism and constructivism in Southeast Asian security studies today: a review essay', The Pacific Review, 15:1 (2002), p. 120; Frank Schimmelfennig, 'NATO's Enlargement to the East: An Analysis of Collective Decision-making', EAPC-NATO Individual Fellowship Report, 2000 (1998), pp. 6-7; see also Sean M. Lynn-Jones, 'Offense-defense theory and its critics', Security Studies, 4:4 (1995), pp. 660-91.
} 
powers - states that are satisfied with the military balance but wish to change, say, the rules of the game. This might result, in crude terms, either from, first, prior shifts in the distribution of capabilities that favour states already interested in altering international order or, second, from the emergence of reformist inclinations among states already capable of challenging the status quo.

Thus, in hegemonic systems, a hegemon that turns against its own order may, in principle, provoke other status-quo states to increase their own capabilities in order to check those efforts, or to decouple their security from the hegemon in order to better able to resist its counter-order activities. Randall Schweller and Xiaoyu Pu argue that 'under unipolarity ... balancing becomes the very definition of revisionism; the goal of restoring a global balance of power requires the overthrow of the existing unipolar structure'. But this only holds if we fail to disaggregate order and the distribution of capabilities. Rising challengers, therefore, need not 'delegitimize the hegemon's global authority and order ${ }^{52}$ to provoke balancing; balancing can derive from the legitimacy of the order and the hegemon's loss of authority by adopting a more reformist orientation. Along these lines, what sometimes looks like hegemonic revisionism may come closer to hegemonic positionalism. That is, a declining hegemon may seek to alter the distribution of capabilities in order to maximise its bargaining leverage against reformist (or revolutionary) states.

To complicate matters, contemporary understandings of revisionism may 'bake in' assumptions from historically specific international orders. As Michael Howard argues of late medieval Europe, the ruling aristocracy regarded 'peace ... as a brief interval between wars' that they filled with activities 'to keep them fit for the next serious conflict'. And 'if European culture in the sixteenth century was becoming secularized, it nonetheless remained bellicose. Indeed, the entire apparatus of the state primarily came into being to enable princes to wage war. With few exceptions, these princes still themselves, and were seen by their subjects, essentially as warrior leaders, and they took every opportunity to extend their power. ${ }^{53}$ In such an international order, even attempts to alter the balance of power for expansionist purposes may be more positionalist than order-revisionist.

Here, the problem of territorial adjustment looms. Are attempts to adjust the distribution of territory (or territorial goods) expression of positional, reformist, or revolutionary orientations? This depends, according to our framework, on the purposes of territorial expansion, and on the legitimacy of forceful territorial change within the bounds of the status-quo order. In some cases, territorial expansion has been sought as a means of increasing material power, and forceful territorial change has been widely viewed as a legitimate practice. Under these circumstances, territorial adjustment might be coded as an instance of positional revisionism. In the post-Second World War international order, by contrast, annexation is understood to be prima facie illegitimate. ${ }^{54}$ Thus, to forcefully annex territory in 2014 signals counter-order revisionism (whether more reformist or more revolutionary), but it did not necessarily do so in other times and places.

It follows that we need to be careful about what we consider counter-order revisionism in the first place. This reinforces the importance of keeping it analytically and empirically distinct from counter-capabilities revisionism. In real-world contexts it is quite possible for actors to score high on counter-capabilities revisionism but low on counter-order revisionism - that is, to locate somewhere close to the positionalist ideal type in our property space - even when they adopt expansionist policies.

\footnotetext{
${ }^{52}$ Randall L. Schweller and Xiaoyu Pu, 'After unipolarity: China's visions of international order in an era of U.S. decline', International Security, 36:1 (2011), pp. 45, 55.

${ }^{53}$ Michael Howard, The Invention of Peace: Reflections on War and International Order (New Haven: Yale University Press, 2000), pp. 12, 15 .

${ }^{54}$ Tanisha M. Fazal, State Death: The Politics and Geography of Conquest, Occupation, and Annexation (Princeton: Princeton University Press, 2011).
} 


\section{Reformist states}

We refer to the combination of counter-order dissatisfaction and satisfaction with the distribution of capabilities as 'reformism'. This is not intended as a normative statement. Even though they are satisfied with the prevailing distribution of military capabilities, ideal-typical reformist states may desire deep changes in other areas of international order. How is this possible? Consider three scenarios.

First, states may seek changes in areas of international order besides the distribution of capabilities for purely domestic reasons. For example, the international economic order may look unfavourable to politically ascendant economic sectors or interests; or a newly empowered coalition may dislike the international order for ideological reasons. ${ }^{55}$ Second, reformist efforts may be aimed at maintaining the current distribution of power. For example, actors might seek to engineer elements of international order in ways that forestall potential future adverse shifts in the distribution of capabilities. Third, states might seek changes in various elements of international order to reduce existing, or potential, threats resulting from the current distribution of power. For example, in hegemonic systems second-tier powers may see a growing threat of predation from the dominant power. Thus, they may want to alter the order - by, say, promoting institutional or normative constraints on military intervention - so as to restrain the dominant power. Similar logics might hold in systems with great power concerts or other arrangements.

In the real world, of course, we will not find purely reformist states. Most reform-oriented actors will have at least some discomfort with the prevailing distribution of power or trajectories of change in military capabilities. Even domestic motivations for changing or conserving international order, including ideological ones, seldom develop in isolation from changing relative capabilities. ${ }^{56}$ Thus, much of the current antipathy towards the liberal order - reformist dispositions - in 'the West' likely connects to real and perceived shifts in global power. Still, reformist dissatisfaction is likely more important for understanding contemporary Western revisionism especially in the United States - than dissatisfaction with the current distribution of power.

To the extent that the United States, whether during the Bush or Trump administrations, can be classified as a 'revisionist hegemon', we suspect that dissatisfaction with institutional, normative, or international economic elements of order are more important than dissatisfaction with the distribution of power. Hegemons generally want to conserve a distribution of power that favours them, and thus seek to reform international order in ways that, at least in part, their leadership believes will accomplish this task. The reformist character of the Bush administration, in particular, probably helps explain the lack of traditional counterbalancing among America's great power allies. The United States was not taking steps that risked significantly altering the place of its second-tier partners in the global distribution of power. ${ }^{57}$ The Trump administration's revisionist bent - while driven by different dynamics and carrying different kinds of dangers for other actors - is similarly aimed, at least with respect to American allies, less at altering the distribution of capabilities than at rejecting other core elements of the liberal international order. ${ }^{58}$

\footnotetext{
${ }^{55}$ Terrence L. Chapman, Patrick J. McDonald, and Scott Moser, 'The domestic politics of strategic retrenchment, power shifts, and preventive war', International Studies Quarterly, 59:1 (2015), pp. 133-44; John M. Owen, The Clash of Ideas in World Politics: Transnational Networks, States, and Regime Change, 1510-2010 (Princeton, NJ: Princeton University Press, 2012); Philpott, 'Usurping the sovereignty of sovereignty?'.

${ }^{56}$ Seva Gunitsky, Aftershocks: Great Powers and Domestic Reforms in the Twentieth Century (Princeton: Princeton University Press, 2017).

${ }^{57}$ Trump's articulation of 'America First' foreign policy is not only more reformist - questioning the basic underpinnings of the American-led security and economic order - but in ways that might negatively implicate the distribution of capabilities from the perspective of, say, America's European allies. But the implications of this, let alone the diagnoses itself, remains provisional.

${ }^{58}$ Steven Ward, 'Logics of stratified identity management in world politics', International Theory (forthcoming), pp. 46-9.
} 


\section{Status-quo states}

In our typology, ideal-typical status-quo states are largely identical to ideal-typical status-quo states in one-dimensional approaches to revisionism. They are satisfied with both the distribution of power and the broader international order. Thus, we emphasise that, per Schweller, as actors become more status-quo oriented, they become more resistant to change in the distribution of power and the international order. ${ }^{59}$ This makes them potentially more conflict-prone in the face of more reformist, positionalist, or revolutionary actors.

However, note that increasing status-quo orientation along one dimension may produce increasing revisionism along another - the more strongly committed a state is to preserving the status quo in one area, the more committed to change it may be in the other. One-dimensional approaches miss this possibility - an error that can lead to mistaken coding of state dispositions, diagnoses of the causes of behavioural change, and policy prescriptions.

\section{The power politics of order: Beyond soft and hard balancing}

This section further deploys our ideal-typical typology, and its property space, to synthesise and illuminate a number of debates about hegemony, power politics, and international order. We begin with a discussion of soft balancing. We argue that accounts of soft balancing implicitly draw a distinction between balance-of-power and international-order revisionism; making that distinction explicit helps to make sense of aspects of the debate. However, it also highlights the need to move beyond the 'soft balancing' and 'hard balancing' debate, as well as its connection with unipolarity, to appreciate broader dimensions of power politics. After discussing those dimensions, we develop the (synthetic) idea of international goods substitution as a logic by which actors contest or uphold the balance of power, international order, or both.

\section{'Soft balancing'}

In its current manifestation, the idea of soft balancing developed to emphasise ways that states might counter American policies and influence short of military counterbalancing. The immediate puzzle concerned the lack of traditional military balancing against the United States, especially after the Bush doctrine made America putatively more threatening to its allies and partners. ${ }^{60}$

According to Robert A. Pape, 'the key reason' that states did not balance against the United States in the 1990s was that 'until' the Bush doctrine 'the United States enjoyed a robust reputation for nonaggressive intentions toward major powers and lesser states beyond is own hemisphere'. However, 'major powers are already engaging in the early stages of balancing behavior against the United States'. Because 'directly confronting U.S. preponderance is too costly for any individual state and too risk for multiple states operating together' it follows that 'major powers are likely to adopt what [Pape calls] "soft balancing" measures: that is, actions that do not directly challenge U.S. military preponderance but that use nonmilitary tools to delay, frustrate, and undermine aggressive unilateral U.S. military policies' ${ }^{61}$

T. V. Paul describes soft balancing as involving 'the formation of limited diplomatic coalitions or ententes, especially in the United Nations, with the implicit threat of upgrading their alliances if the United States goes beyond its stated goals'. He argues that soft balancing occurs under three

\footnotetext{
${ }^{59}$ Schweller, 'Bandwagoning for profit'.

${ }^{60}$ Stephen G. Brooks and William C. Wohlforth, 'Hard times for soft balancing', International Security, 30:1 (2005), pp. 72-108; Judith Kelley, 'Strategic non-cooperation as soft balancing: Why Iraq was not just about Iraq', International Politics, 42:2 (2005), pp. 153-73; Robert A. Pape, 'Soft balancing against the United States', International Security, 30:1 (2005), pp. 7-45; T. V. Paul, James J. Wirtz, and Michel Fortman (eds), Balance of Power: Theory and Practice in the 21st Century (Stanford, CA: Stanford University Press, 2004); Beth Elise Whitaker, 'Soft balancing among weak states? Evidence from Africa', International Affairs, 86:5 (2010), pp. 1109-27.

${ }^{61}$ Pape, 'Soft balancing against the United States', pp. 9-10.
} 
conditions. First, 'the hegemon's power position and military behavior are of growing concern' but do not yet threaten the 'sovereignty of second-tier powers'. Second, 'the dominant state is a major source of public goods in both economic and security areas that cannot simply be replaced'. Third, 'the dominant state cannot easily retaliate either because the balancing efforts of others are not overt or because they do not directly challenge the power position with military means'. ${ }^{62}$

Since these early statements, some have expanded the concept to include 'economic' and 'diplomatic' balancing, such as the provision of aid, the formation of new institutions, and many other activities that alter the balance of influence - both military and non-military - among states. ${ }^{63}$ In these formulations, 'hard' or 'traditional' balancing generally involves directly increasing military power via internal buildups or external alliances, and 'soft' balancing involves the use of non-military instruments. But, to complicate matters, some argue that soft balancing includes 'limited arms buildup' and 'cooperative exercises' that might be 'converted to open, hardbalancing strategies' in the future. ${ }^{64}$

Many reject the notion of soft balancing altogether. Some argue that it represents a rearguard, concept-stretching effort to salvage balance-of-power theory in light of the fact that no secondtier powers balanced against the United States in the 1990s and 2000s. ${ }^{65}$ Others stress that it inflates normal 'diplomatic friction' into balancing behaviour. ${ }^{66}$ But, the 'major problem with the soft balancing concept is, in fact, one of analytical coherence': it collapses, for example, 'strategies to reduce imbalances in military capabilities that rely on instruments other than military mobilization or alliance formations' and 'efforts to reduce imbalances in power and influence beyond those directly involving military capabilities' ${ }^{67}$

As those seeking to extend the concept of soft balancing argue, there is no necessary connection between unipolarity (or hegemony) and so-called soft balancing. Actors use a variety of nonmilitary instruments to shape the balance of military capabilities in both unipolar and non-unipolar systems. ${ }^{68}$ This also means that a lot of what looks like soft balancing is not about shaping the balance of military capabilities at all, but rather elements of international order. For example, power-political efforts - regardless of whether or not they use military instruments - may be largely status-quo oriented, such as when an actor uses military, economic, and other instruments to uphold the current distribution of capabilities and the current international order. Indeed, in conventional hegemonic-stability and power-transition theory, this is precisely the typical behaviour of predominant powers.

This returns us to the importance of disaggregating revisionism in the context of hegemonic powers and their allies. Paul's discussion of 'soft balancing' by US allies in the run-up to the Iraq War repeatedly describes their primary reason for opposition in terms of upholding existing international norms. These efforts may not be best understood as balancing but rather as

\footnotetext{
${ }^{62}$ T. V. Paul, 'Soft balancing in the age of U.S. primacy', International Security, 30:1 (2005), pp. 47, 59.

${ }^{63} \mathrm{See} \mathrm{Kai} \mathrm{He}$, 'Institutional balancing and International Relations theory: Economic interdependence and balance of power strategies in Southeast Asia', European Journal of International Relations, 13:3 (2008), pp. 489-518.

${ }^{64}$ T. V. Paul, 'Introduction: the enduring axioms of balance of power theory and their contemporary relevance', in T. V. Paul, James J. Wirtz, and Michel Fortman (eds), Balance of Power: Theory and Practice in the 21st Century (Stanford, CA: Stanford University Press, 2004), p. 3.

${ }^{65}$ William C. Wohlforth, Stuart J. Kaufman, and Richard Little, 'Introduction: Balance and hierarchy in international systems', in Stuart Kauffman, Richard Little, and William Wohlforth (eds), The Balance of Power in World History (New York: Palgrave, 2007), p. 3.

${ }^{66}$ Keir A. Lieber and Gerard Alexander, 'Waiting for balancing: Why the world is not pushing back', International Security, 30:1 (2005), p. 110.

${ }^{67}$ Daniel H. Nexon, 'The balance of power in the balance', World Politics, 61:2 (2009), p. 343. Indeed, some of the activities that potentially fall under the rubric of 'soft balancing' basically amount to half-baked military balancing. See Nexon, ibid., p. 344.

${ }^{68}$ Non-military instruments may prove more attractive in unipolar systems than bipolar or multipolar ones, but that's an empirical question.
} 
opposition to the Bush administration's own attempts to revise salient institutional and normative aspects of international order - that is, the use of a variety of power-political instruments by weaker, more status-quo powers to check a reformist hegemon. ${ }^{69}$ This also tracks with Judith Kelley's contention that European opponents of the invasion of Iraq primarily wanted to maintain their position as partners in the American-led international order: to avoid being 'sidelined in future global security decision-making, ${ }^{70}$

Compare this formulation to Stephen M. Walt's discussion of soft balancing. Walt develops a linear continuum of alliance behaviour under unipolarity, with 'hard balancing' being the most opposed to the unipolar power and 'regional balancing' (against those seeking to challenge the unipolar power) most supportive. For Walt, soft balancing occupies the 'most opposed' position prior to hard balancing. Thus, he argues that 'soft balancing accepts the current balance of power but seeks to obtain better outcomes within it, by assembling a countervailing coalition designed to thwart or impede specific policies, ${ }^{71}$ In our terms, status-quo actors will try to find ways to check a reformist unipolar power without threatening to significantly revise the balance of power. It is not surprising, then, that we saw neither traditional military balancing from American allies in 2002-03 - these states were broadly satisfied with the current balance of power - nor pro-order efforts that seriously threatened American primacy. ${ }^{72}$

Non-hegemonic actors are likely to use non-military instruments to 'thwart or impede specific policies' pursued by a hegemon whenever these either challenge a satisfactory element of the status-quo or bolster an unsatisfactory one. The soft-balancing debate thus rightly pushes realists to pay more attention to the power-political significance of non-military instruments. But because participants fail to consistently distinguish, in analytic terms, between the balance of power and other elements of international order, they further risk turning 'soft balancing' into a category that assimilates all power-political activity short of traditional military balancing. ${ }^{73}$

\section{Power politics and international goods substitution}

States routinely draw from a toolkit of different instruments - military, economic, diplomatic, cultural, institutional, and so on - to influence the behaviour of other actors in international politics. They deploy these instruments in ways that likely reflect a limited number of logics. Stacie Goddard and Daniel Nexon contend that these logics fall under two very large baskets: first, 'integration', which includes internal military mobilisation and the pooling of military capabilities in alliances, as well as efforts to 'bind' actors in ways that limit their autonomy; and, second, 'fragmentation', which includes wedge strategies aimed at breaking apart domestic or international coalitions. $^{74}$

This broad conception of the instruments, and objectives, involved in power-political manoeuvres accords well with our typology. It describes two major aims of power-political manoeuvres: first, attempts to influence the distribution of military-security goods (the balance of power) and, second, attempts to influence the other distributive and constitutive elements

\footnotetext{
${ }^{69}$ Paul, 'Soft balancing in the age of U.S. primacy', pp. 59. 64-70.

${ }^{70}$ Kelley, 'Strategic non-cooperation as soft balancing', p. 167.

${ }^{71}$ Walt, 'Alliances in a unipolar world', pp. 101, 103-04.

${ }^{72}$ Stephen G. Brooks and William C. Wohlforth, 'International Relations theory and the case against unilateralism', Perspectives on Politics, 3:3 (2005), pp. 509-24.

${ }^{73}$ Brock Tessman and Wojtek Wolfe, 'Great powers and strategic hedging: the case of Chinese Energy Security Strategy', International Studies Review, 13:2 (2011), p. 218.

${ }^{74}$ Goddard and Nexon, 'The dynamics of global power politics', pp. 7-9; see also Timothy W. Crawford, 'Preventing enemy coalitions: How wedge strategies shape power politics', International Security, 35:4 (2011), pp. 155-89; Stacie E. Goddard, 'When right makes might: How Prussia overturned the European balance of power', International Security, 33:3 (2008), pp. 110-42; Stacie E. Goddard, When Right Makes Might: Rising Powers and World Order (Ithaca, NY: Cornell University Press, 2018); Yasuhiro Izumikawa, 'Binding strategies in alliance politics: the Soviet-Japanese-US diplomatic tug of war in the mid-1950s', International Studies Quarterly, 62:1 (2018), pp. 108-20.
} 
of international order. ${ }^{75}$ Thus, states might seek anything from conserving the existing balance of power, to making regional or dyadic adjustments aimed to correct a local security deficit, to altering the number or identity of great powers in the international system. Similarly, states may seek anything from defending the current international order, to making limited adjustments, to its complete overhaul.

Thus, states can, as reflected in putative examples of 'soft balancing', engage in fairly intense power-political behaviour even when they support, or are indifferent to, the existing distribution of military capabilities in the system. For example, Brock Tessman and Wojtek Wolfe develop an understanding of 'strategic hedging' as response to power transitions, in which second-tier states substitute their own provision of 'public goods and subsidies' for those provided by the hegemon. ${ }^{76}$ Some actors engage in such substitution with the aim of altering, to varying degrees, the distribution of capabilities, broader aspects of international order, or both. But more statusquo actors hedge because they worry that as 'the leading state sees its power advantage erode, it may choose to reduce or eliminate some or all of the public goods and subsidies it provides' ${ }^{77}$ It follows that dominant powers - hegemonic polities, great power cartels, and so on - that show evidence of how reformist dispositions may trigger goods substitution. This may happen in the absence of hegemonic decline; it may even take place if the dominant actor seeks to reform the international order by expanding its provision of goods - if it does so in ways that trigger opposition among actors that favour the status-quo international order.

Strategic hedging is likely a subset of what we have termed international goods-substitution dynamics. That is, those in which actors alter their portfolio of security, economic, cultural, or other goods. When actors find the quality or quantity of a good wanting, they have incentives to expand or change their stock of that good. They can do so by seeking new arrangements from a current external supplier, by trying to expand their own production of that good, or by turning to alternative suppliers. ${ }^{78}$ For instance, Nexon argues that states may use 'public goods substitution' as a form of balancing or as part of a bid for domination: 'states seeking to enhance their political autonomy and perhaps weaken the influence of another state in a region or issue-area may form arrangements to provide public goods equivalent to those offered by another state or coalition of states' ${ }^{79}$ These kinds of 'efforts might provide exit options to actual or potential clients, reduce the ability of a state to meddle in other states' internal affairs, and otherwise reduce the costs of dependency upon the target of a balancing' or divide-and-rule policies. ${ }^{80}$

Of course, military, economic, cultural, status, and other goods are not simply provided by hegemons, great powers, or regional actors. States can produce them on their own, or in partnership with other states - whether via, for example, security alliances or international-lending institutions. The quality and quantity of international goods sometimes have an emergent quality; phrases such as a negative 'strategic environment' capture the central idea here: that the good of military security is generated not just by allies, but also by adversaries and the interdependent and unintentional effects of the military-security practices of others. ${ }^{81}$ As this should make clear, not all of the goods at stake are public. They include goods that might be better characterised as club, private, or common. ${ }^{82}$

\footnotetext{
${ }^{75}$ As we noted earlier, 'balance of power' (the distribution of military capital) is actually a subset of international order. We return to this in the conclusion.

${ }^{76}$ Tessman and Wolfe, 'Great powers and strategic hedging', pp. 219-20.

${ }^{77}$ Ibid., p. 220.

${ }^{78}$ Even when they do not combine these strategies, they implicitly or explicitly weigh them against one another.

${ }^{79} \mathrm{Nexon}$, 'The balance of power in the balance', p. 346

${ }^{80}$ See also Izumikawa, 'Binding strategies in alliance politics'.

${ }^{81}$ Barry Buzan, People, States, and Fear, 2nd edn (Colchester, UK: European Consortium For Political Research Press, 2008), pp. 90, 163; Jae Jeok Park, 'The US-led alliances in the Asia-Pacific: Hedge against potential threats or an undesirable multilateral security order?', The Pacific Review, 24:2 (2011), pp. 137-58.

${ }^{82}$ Goods vary in terms of whether they are, on the one hand, rivalrous or non-rivalrous or, on the other hand, excludible or non-excludible. These combine, in ideal-typical terms, to produce private goods (rival and excludable), such as 'cars, clothes, food'; club goods (non-rival and excludable), such as 'cable television'; public goods (non-rival and non-excludable), such as
} 
In this context, recall Jason W. Davidson's definition of revisionist states - as 'those states who seek to change the distribution of goods' in the international system. If we adopt such an approach, it suggests that international order is something like an ecology of military, economic, status, and other goods. ${ }^{83}$ Of course, it is not just the distribution of goods that forms part of that ecology. It is also the character and nature of those goods - the 'rules' and 'norms' associated with them. ${ }^{84}$ Thus, our typology breaks out one dimension of that ecology - the balance of military capabilities - from other dimensions.

That ecology comes under strain during power transitions precisely because new actors emerge with the ability to provide, say, economic, security, and diplomatic goods. ${ }^{85}$ Dominant actors themselves may be less able, or less willing, to provide those goods themselves. Even if dominant actors remain committed to supplying public, private, and club goods, the greater availability of alternative suppliers - of exit options - affects the calculations of other states. ${ }^{86}$ In hegemonic systems, the dominant power enjoys a near monopoly on the provision of international goods. No other state can, for example, provide credible security commitments. But as the hegemon declines, this changes, and thus the disposition of other actors towards the balance of power and the prevailing international order becomes rather important. ${ }^{87}$

Thus, some of what falls under the rubric of 'soft balancing' involves efforts at international goods substitution. The difference between 'hard' and 'soft' balancing, then, pertains to the instruments - or substantive kinds of goods - at stake. For example, states that want to alter the distribution of power are likely to engage in coordinated diplomatic efforts in pursuit of that objective. They may do so without pursuing much in the way of hard balancing efforts at all, perhaps because the costs are too high or they lack the capabilities to do so. States may also bandwagon - in terms of alliance politics - with the hegemon while simultaneously seeking to alter (or conserve) the international order.

States that decide to undertake conventional military balancing are engaging in a specific form of international goods substitution; the complex military-security ecology they operate in generates, in their view, an inadequate provision of security. They seek to rectify that condition by substituting: through, for example, increasing their indigenous production of military security; by jointly producing military security; by seeking a patron to provide them with military security; or by reconfiguring their alliance and partnership portfolios to include new, or exclude existing,

\footnotetext{
'air, public parks, national defence'; and common goods (rival and non-excludable), such as 'water, fisheries'. Hella Engerer, 'Security as a public, private or club good: Some fundamental considerations', Defence and Peace Economics, 22:2 (2011), pp. 136-7.

${ }^{83}$ Davidson, The Origins of Revisionist and Status-Quo States, p. 14. Work on alliances and the joint-production of security goods points to how the intentional provision of a good may shift the overall security ecology. Mutually Assured Destruction forms of nuclear deterrence, for example, created 'public benefits' for the NATO and therefore encouraged free riding across security contributions. Sandler and Hartley, 'Economics of alliances', p. 879. But, more generally, NATO's overall production of security to its members - as a club good - impacts the security landscape in the region. Moscow appears to perceive it as diminishing the quality of its own security, despite protestations that NATO expansion enhances Russian security by eliminating the pernicious effects of a 'power vacuum' in Eastern and Central Europe. A similar disagreement persists with respect to the effects of American security provision in East Asia. Along related lines, Krebs argues that NATO's provision of security to Greece and Turkey against the Soviet Union altered their security ecologies in ways that exacerbated their rivalry. Ronald R. Krebs, 'Perverse institutionalism: NATO and the Greco-Turkish conflict', International Organization, 53:2 (1999), pp. 343-77.

${ }^{84}$ This is consistent with Ward's (Status and the Challenge of Rising Powers, ch. 1) treatment of institutions, rules, and norms as functioning in part to constitute and naturalise the distribution of goods..

${ }^{85} \mathrm{Kei}$ Koga, 'The concept of "hedging” revisited: the case of Japan's foreign policy strategy in East Asia's power shift', International Studies Review, 20:4 (2017), p. 7; Larson, 'New perspectives on rising powers and global governance', pp. 2-3.

${ }^{86}$ Gunitsky, Aftershocks.

${ }^{87}$ Tessman and Wolfe, 'Great powers and strategic hedging', pp. 220-1.
} 
suppliers of military security. ${ }^{88}$ States trying to revise the balance of military capabilities also do this, but with different objectives. Similarly, actors may engage in military goods substitution primarily to revise or conserve other elements of international order - that is, use military instruments for purposes unrelated, at least directly, to balancing.

Why focus on this broader logic? Consider the expanding literature on alternative-order building. In a 2007 Foreign Policy article, Moisés Naim argued that China, Venezuela, and other regimes were replacing foreign assistance from responsible donors with 'rogue aid'. Rather than use development assistance to fight corruption and improve human rights, these countries sought only to 'further their own national interests, advance an ideological agenda, or sometimes line their own pockets' ${ }^{89}$ Naim's account downplayed the role of such motivations in Western development assistance, ${ }^{90}$ but his argument anticipated a wave of work on how the rise of illiberal international donors might reshape international order. ${ }^{91}$ Now, a growing body of literature examines how, for example, new institutions - such as the Asian Infrastructure Investment Bank (AIIB) and the Shanghai Cooperation Organization (SCO) - and Chinese aid - including the One Belt, One Road initiative - might be altering both international norms and the balance of influence in world politics. ${ }^{92}$

The standard hegemony-studies story holds that status-quo oriented rising powers will shift the system towards something increasingly resembling a great power cartel that upholds the general order. But a world in which a reformist hegemon confronts status-quo second-tier powers will, first, likely produce power-political competition over the distribution of non-military goods, and, second, risk making some those second-tier powers more positionalist in their orientations.

International goods substitution processes, whether involving a reformist or more status-quo hegemon, can erase hegemony even short of direct efforts to shift the balance of military capabilities. The collapse of hegemony - the control that the dominant power exercises over the

\footnotetext{
${ }^{88}$ Compare Richard Cornes and Todd Sandler, The Theory of Externalities, Public Goods, and Club Goods (Cambridge: Cambridge University Press, 1996); Tongfi Kim, The Supply Side of Security: A Market Theory of Military Alliances | Tongfi Kim (Stanford, CA: Stanford University Press, 2016); Park, 'The US-led alliances in the Asia-Pacific'.

${ }^{89}$ Moisés Naim, 'Rogue aid', Foreign Policy, March/April (2007).

${ }^{90}$ Julia Bader, 'China, autocratic patron? An empirical investigation of China as a factor in autocratic survival', International Studies Quarterly, 59:1 (2015), pp. 23-33.

${ }^{91}$ Ngaire Woods, 'Whose aid? Whose influence? China, emerging donors and the silent revolution in development assistance', International Affairs, 84:6 (2008), pp. 1205-21.

${ }^{92}$ These examples raise threshold questions. We would not normally think of a state seeking, for example, more international aid donors as necessarily trying to alter international order, even though it is seeking to alter the distribution of a set of goods. But we do tend to scrutinise the formation of new development institutions - such as the AIIB as potentially revisionist. This was certainly the view of the Obama administration when it pressured allies not to join the AIIB. See Mathias Sobolewski and Jason Lange, 'US urges allies to think twice before joining China-led bank', Reuters (2015). And, as noted above, many worry that Chinese development assistance and trade are hollowing out liberal international order, regardless of whether or not Beijing also intends to alter the global balance of power through these efforts. These threshold questions pose less of an immediate problem when we remind ourselves that no power-political manoeuvre will ever be purely status quo or revisionist in orientation; and those that fall toward the middle of the spectrum will tend to be indifferent, mixed, or ambivalent with respect to continuity and change. For explorations of these dynamics under various labels, see Karen J. Alter and Sophie Meunier, 'The politics of international regime complexity', Perspectives on Politics, 7:1 (2009), pp. 13-24; Alexander Cooley, Great Games, Local Rules: The New Great Power Contest in Central Asia (Oxford: Oxford University Press, 2012); Alexander Cooley and Daniel Nexon, “The empire will compensate you": the structural dynamics of the U.S. overseas basing network', Perspectives on Politics, 11:4 (2013), pp. 1034-50; Gustavo A. Flores-Macias and Sarah E. Kreps, 'The foreign policy consequences of trade: China's commercial relations with Africa and Latin America, 19922006', The Journal of Politics, 75:2 (2013), pp. 357-71; Scott L. Kastner, 'Buying influence? Assessing the political effects of China's international trade', Journal of Conflict Resolution, 60:6 (2014), pp. 980-1007; Joshua Kurlantzick, Charm Offensive: How China's Soft Power Is Transforming the World (New Haven, CT: Yale University Press, 2007); Larson, 'New perspectives on rising powers and global governance'; Amandine Orsini, Jean-Frédéric Morin, and Oran Young, 'Regime complexes: a buzz, a boom, or a boost for global governance?', Global Governance: A Review of Multilateralism and International Organizations, 19:1 (2013), pp. 27-39.
} 
distribution and character of international goods - simply requires some mixture of counterorder revisionists or even relative indifference by second-tier powers. It does not necessarily depend on the 'big bang' of a hegemonic war triggered by the conflict between a status-quo hegemon and a rising revolutionary state. Of course, such dynamics will have dramatic effects on the broader balance of influence in world politics, and, ultimately, on the balance of military capabilities as the hegemon sees reduced leverage over, or outright loss of, clients and allies. The key point is that we do not need to have significant balance-of-capabilities revisionism to unravel hegemonic orders. This means, in turn, that the use of non-military instruments to shape, perhaps even incrementally, the distribution of non-military international goods cannot be dismissed as mere 'diplomatic friction': the stakes can be very high when it comes to the politics of international order.

\section{Conclusions}

This article developed the distinction between revisionism aimed at altering the balance of military power and revisionism aimed at altering other elements of the international order. While similar distinctions implicitly exist in the literature, they are often collapsed into a unidimensional continuum ranging from status-quo to revisionist orientations. Making explicit the twodimensional property space, we argued, allows for a more nuanced understanding of debates over 'revisionist' hegemons, and contributes to debates about broad conceptions of power politics. In particular, it highlights international order as a dimension of power-political contestation that may be distinct from contestation over the distribution of capabilities; and it focuses attention on a logic of international goods substitution found in theories of strategic hedging, work on alternative-order building, and soft balancing. We emphasise the logic of international goods substitution because, in part, it follows directly from an understanding of international order as the existing distribution of status, economic, institutional, and other goods. This suggests that we can think of international orders as, at least in part, ecologies of public, club, and private goods and their associated rules, norms, and arrangements.

However, this means that the balance of military capabilities is actually itself a subset of international order. We have chosen to hive off the distribution of capabilities from the rest of international order for analytical purposes, not because there is anything natural or necessary about this distinction. Indeed, the notion of the international order is itself a fairly crude simplification. Scholars already draw distinctions between, say, status goods, military capabilities, and economic dimensions of order. ${ }^{93}$ States and other actors exist in a complex ecology of goods that differs not only by issue-area, but across time and space. ${ }^{94}$ Here, tools derived from field theory, which would parse dimensions of international order as specific fields and international goods in terms of field-relevant capital, might bridge realist-inflected and more social-constructionist approaches. ${ }^{95}$ Regardless, nothing in our approach precludes IR scholars from further disaggregating military and non-military goods.

\footnotetext{
${ }^{93}$ See Larson, 'New perspectives on rising powers and global governance'; Ward, Status and the Challenge of Rising Powers.

${ }^{94}$ Compare Amitav Acharya, 'The emerging regional architecture of world politics', World Politics, 59:4 (2007), pp. 629-52; Emanuel Adler and Patricia Greve, 'When security community meets balance of power: Overlapping regional mechanisms of security governance', Review of International Studies, 35:S1 (2009), pp. 59-84; Mattern and Zarakol, 'Hierarchies in world politics'; Norrlof, America's Global Advantage; Carla Norrlof, 'Dollar hegemony: a power analysis', Review of International Political Economy, 21:5 (2014), pp. 1042-70.

${ }^{95}$ Rebecca Adler-Nissen (ed.), Bourdieu in International Relations: Rethinking Key Concepts in IR (New York: Routledge, 2012); Bigo, America's Global Advantage; Julian Go, 'Global fields and imperial forms: Field theory and the British and American empires', Sociological Theory, 26:3 (2008), pp. 201-27; Julian Go and Monika Krause, 'Fielding transnationalism: an introduction', The Sociological Review, 64:2, suppl. (2016), pp. 6-30; Nexon and Neumann, 'Hegemonic-order theory'; Vincent Pouliot, International Pecking Orders: The Politics and Practice of Multilateral Diplomacy (Cambridge: Cambridge University Press, 2016).
} 
Still, the typology we offer here has heuristic value. It captures an important distinction - both in IR theory and policy discourse - between the balance of military power and other aspects of international order. It should, even in its simplified form, help us to think through the various possible interactions between, on the one hand, different kinds of hegemonic revisionisms and, on the other hand, the dispositions of second-tier and rising powers with respect to international order and the balance of power. Given the current leadership of the United States and the fluid character of contemporary world politics, we need more nuanced accounts of revisionist and status-quo orientations.

Author ORCIDs. (D) Daniel Nexon, 0000-0002-4163-0450; Steven Ward, 0000-0001-6084-2785.

Acknowledgments. We thank the editors at the Review of International Studies, Morten Anderson, Rebecca Adler-Nissen, Julia Bader, Benjamin de Carvalho, Halvard Leira, Iver Neumann, Bahar Rumelili, Ole Jacob Sending, Ann Towns, and participants at numerous conferences and workshops. We apologise to those that we have inadvertently omitted from this list. This article was funded by the Norwegian Research Council under the project 'Undermining Hegemony', project no. 240647.

Alexander Cooley is Claire Tow Professor of Political Science at Barnard College and Director of the Harriman Institute at Columbia University. Author's email: acooley@barnard.edu

Daniel Nexon is Associate Professor in the Department of Government and School of Foreign Service at Georgetown University. Author's email: dhn2@georgetown.edu

Steven Ward is Assistant Professor in the Department of Government at Cornell University. Author's email: smw347@cornell.edu

Cite this article: Cooley, A., Nexon, D., Ward, S. 2019. Revising order or challenging the balance of military power? An alternative typology of revisionist and status-quo states. Review of International Studies 45, 689-708. https://doi.org/10.1017/ S0260210519000019 